\title{
Assessment of Heavy Metal Pollution of the Peter the Great Bay (North-West Pacific Region) Using Brown Algae
}

\author{
Svetlana Kozhenkova1, Elena Chernova ${ }^{1,2}$ \\ ${ }^{1}$ Pacific Geographical Institute, Far Eastern Brunch, Russian Academy of Sciences, Vladivostok, Russia \\ ${ }^{2}$ Far East Federal University, Vladivostok, Russia \\ Email: svetlana@tigdvo.ru, elena@tigdvo.ru
}

How to cite this paper: Kozhenkova, S., \& Chernova, E. (2020). Assessment of Heavy Metal Pollution of the Peter the Great Bay (North-West Pacific Region) Using Brown Algae. Journal of Geoscience and Environment Protection, 8, 134-146.

https://doi.org/10.4236/gep.2020.810010

Received: September 16, 2020

Accepted: October 13, 2020

Published: October 20, 2020

\begin{abstract}
According to the content of heavy metals $\mathrm{Fe}, \mathrm{Mn}, \mathrm{Cu}, \mathrm{Zn}, \mathrm{Pb}, \mathrm{Cd}$ and $\mathrm{Ni}$ in brown algae Sargassum miyabei from the Peter the Great Bay of the Sea of Japan, geochemical factors were calculated. The algae geochemical anomaly index $\left(\mathrm{I}_{\mathrm{GA}}\right)$ characterizes the degree of excess of the background concentrations of metals. The heavy metal pollution factor $\left(\mathrm{F}_{\mathrm{p}}\right)$ is used to estimate the degree of pollution of the marine environment with heavy metals. The Peter the Great Bay has a low level of heavy metal pollution, but some parts of second-order bays, such as Amurskii Bay, Ussuriiskii Bay and Vostok Bay, have a moderate degree of pollution. The high pollution level was registed on the western coast of the Ussuriiskii Bay near the Vladivostok city landfill. Thirty percent of sampling stations were noted to have higher threshold levels of metals in the algae. These areas need to be monitored to assess their environmental status and measures should be applied to reduce the impact on the environment.
\end{abstract}

\section{Keywords}

Biomonitoring, Heavy Metals, Environmental Quality Regulation, Brown Algae, Sargassum miyabei, North-West Pacific Region

\section{Introduction}

The heavy-metals pollution of the marine environment is the pressing problem. The basis line in the solution of this problem is a decrease in income of contaminants from the main sources of pollution as well as a getting the positive balance between assimilatory capacity of the coastal ecosystem and intensity of the pollution supply (Israel, 1989). Monitoring of the environment is a basis for base 
for making the specific decisions related to quality control of the coastal biogeosystems. The correct assessment of the degree of metal pollution in coastal areas should include the state analysis of different components of the ecosystem including the abiotic (water and bottom sediments) and biotic ones (Burdin, 1985; Khristoforova, 1989; Rainbow \& Phillips, 1993; Chakraborty, Bhattacharya, Singh, \& Maity, 2014).

Brown algae as the accumulative bioindicators are widely used to determine the degree of heavy-metals pollution of the coastal seawaters. The European researchers were the first to use brown algae for the ecological monitoring during the early 1970s (Bryan \& Hummerstone, 1973; Fuge \& James, 1974). Gradually this approach came into use in different regions of the world (Vasquez \& Guerra, 1996; Amado-Filho, Salgado, Rebelo, Rezende, Karez, \& Pfeiffer, 2008).

The research of the heavy metal concentrations in brown algae of the North west Pacific started in 1976 (Khristoforova, Bogdanova, \& Tolstova, 1983; Khristoforova, 1989). Several species of algae species (Costaria costata, Fucus evanescens, Saccharina japonica, Scytosyphon lomentaria, Silvetia babingtonii, Stephanocystis crassipes) were used. Species and age features of the microelement composition of plants under the impact and background conditions were carried out, and the long-term estimates of the metal pollution were performed (Kozhenkova, Khristoforova, \& Chernova, 2000; Shulkin, Chernova, Khristoforova, \& Kozhenkova, 2015).

Two species of the Sargassum genus-Sargassum miyabei and $\mathcal{S}$. pallidum-are widely distributed along the Russian coast of the Sea of Japan and to the south of it. For the first time, these species were used for assessment of heavy metal pollution of the coastal waters in the North west Pacific in late 1970s-early 1980s (Khristoforova, Bogdanova, \& Tolstova, 1983).

Hereupon, different species of Sargassum genus were used as the heavy metal pollution indicators near Vietnam and Brasilia as well as in the East China Sea, Mediterranean Sea and other seas (Ho, 1988; Hou \& Yan, 1998; Chernova, Khristoforova, \& Vyshkvartsev, 2002; Al-Masri, Mamish, \& Budier, 2003; Chernova \& Sergeeva, 2008; Brito, de Souza, Bressy, Moura, \& Korn, 2012; Chernova \& Khristoforova, 2012; Sun, Liu, Jiang, \& Yang, 2019).

The purpose of the article is to assess the heavy metal pollution of the Peter the Great Bay (PGB) with brown alga Sargassum miyabei.

\section{Study Area}

The Peter the Great Bay is located in the northwestern Sea of Japan between $42^{\circ} 17^{\prime} \mathrm{N}$ and $43^{\circ} 20^{\prime} \mathrm{N}, 130^{\circ} 41^{\prime} \mathrm{N}$ and $133^{\circ} 02^{\prime} \mathrm{E}$. The Bay area exceeds $6000 \mathrm{~km}^{2}$. According to the type of the coastal line and bottom relief, the Bay is divided into several parts.

The southwestern part of the Bay is located between the estuary of the Tumen River in the south and the Cape of Bruce in the north. The Far-Eastern State 
Marine Reserve (FESMR) occupies a part of the water area and coastal zone adjacent to it. The Muravyov-Amursky Peninsula, Russki, Popov Islands and a great number of small islands divide the northern Peter the Great Bay into two water areas-Amurskii Bay and Ussuriiskii Bay. Vladivostok city is located in the Muravyov-Amursky Peninsula and Russkii Island. The Strelok, Vostok and Nakhodka Bays are situated further east.

The Tumen River flows into the Sea of Japan on the south boundary of the Peter the Great Bay. Predominance of the southward Primorski Current causes a transportation of the river discharge to the shores of the Korean Peninsula and reigns in the influence of the Tumen River flow on the Russian coastal waters (Shulkin \& Semykina, 2012). The Razdolnaya, Partizanskaya Rivers and a great number of small rivers flow into the PGB.

The total area of the Peter the Great Bay catchment basin is $23,800 \mathrm{~km}^{2}$. About a half of this territory is occupied by forests $\left(10,095 \mathrm{~km}^{2}\right)$ and protected natural areas $\left(1157 \mathrm{~km}^{2}\right)$.

Within the PGB catchment basin reside, 1.3 million people. Here, the cities of Vladivostok (633 thou. people), Ussuriisk (194 thou. people), Artem (114 thou. people), Fokino (31 thou. people), Bolshoi Kamen (40 thou. people), Nakhodka (154 thou. people) and Partizansk (45 thou. people) are situated (Brief..., 2016).

Power, machinery production, woodworking, chemical, textile, food industries, construction and agriculture are basic industries on the territory of the PGB catchment basin. The amount of wastewaters produced within the catchment basin has reduced from 620 million tons in 1990 to 290 million tons in 2015 (Brief..., 2016). The main reason of the wastewater amount reduction is a decline in the industrial production since 1990s.

\section{Materials and Methods}

The brown alga Sargassum miyabei was collected in July-August in 1995, 1998, 2000-2004, 2008, 2010 and 2017, with varying periodicity at 65 stations in the Peter the Great Bay as well as at two stations in the Kievka Bight located north-east of this Bay. The preparation of samples for the chemical analysis was earlier described (Chernova \& Kozhenkova, 2016). The concentrations of Fe, $\mathrm{Mn}, \mathrm{Cu}, \mathrm{Zn}, \mathrm{Pb}, \mathrm{Cd}$ and $\mathrm{Ni}$ in the macrophytes were determined by the atomic absorption spectrophotometry method at Shimadzu 6800 in the Common Use Centre "Center of the Landscape Ecodiagnostics and GIS-technologies" in the Pacific Geographical Institute FEB RAS.

Concentrations of $\mathrm{Fe}, \mathrm{Mn}, \mathrm{Cu}, \mathrm{Zn}$ and $\mathrm{Pb}$ were used for calculation of the geochemical coefficients: algae geochemical anomaly index $\left(\mathrm{I}_{\mathrm{GA}}\right)$ and heavy metal pollution factor $\left(\mathrm{F}_{\mathrm{p}}\right)$ (Figure 1 ). In case of absence $\mathrm{Pb}$ concentrations, $\mathrm{Cd}$ concentrations were used.

Apart from the author's data, the published concentrations of metals in $S$. miyabei from the coastal zone of the Amurskii Bay (2011), Nakhodka Bay 


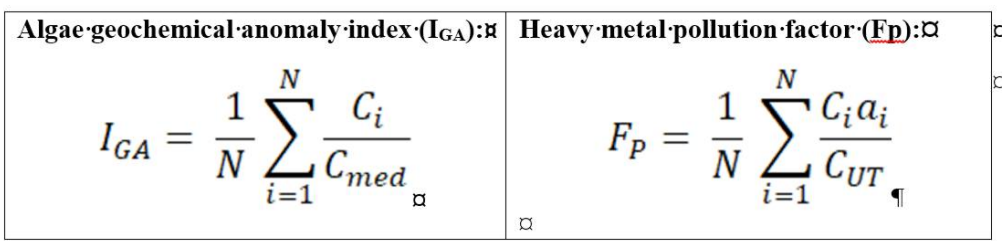

Figure 1. Formulas of the geochemical coefficients: $\mathrm{I}_{\mathrm{GA}}$-algae geochemical anomaly index, and $\mathrm{F}_{\mathrm{p}}$-heavy metal pollution factor. Notations: $\mathrm{C}_{\mathrm{i}}$ is concentration of $i$-metal in $S$. miyabei, $\mathrm{C}_{\text {med }}$ is the background concentration of metal which is equal to median of metal concentrations in the shared dataset for $S$. miyabei from the north-western Sea of Japan (Kozhenkova \& Chernova, 2018), $\mathrm{N}$ is the number of elements used for index, $\mathrm{C}_{\mathrm{UT}}$ is the threshold concentration of metal for this type of algae calculated earlier (Chernova \& Kozhenkova, 2016) as a median plus double median of absolute deviations from median $(\mathrm{Me}+2 \mathrm{MAD}) ; \mathrm{a}_{\mathrm{i}}$ is the danger coefficient of $i$-element depending on danger class of element: $\mathrm{a}=2.5$ in case of I danger class, $\mathrm{a}=1.5$ in case of II danger class $(\mathrm{Cd}, \mathrm{Pb}), \mathrm{a}=1.0$ in case of III danger class $(\mathrm{Cu}), \mathrm{a}=0.5$ in case of IV danger class $(\mathrm{Fe}, \mathrm{Mn})$.

(2012), south-western part of the Peter the Great Bay and around Russki Island (2016) were used (Kobzar \& Kristoforova, 2015; Khristoforova, Gamayunova, \& Afanasyev, 2015; Khristoforova \& Kobzar, 2017; Khristoforova, Emelyanov, \& Efimov, 2018). The stations of macrophyte sampling by the authors of this paper and our colleagues have intersected and, thereby, a total number of points of macrophyte sampling in the Peter the Great Bay reaches 84 stations.

The calculations of $F_{p}$ for some second-order bays which are the parts of the Peter the Great Bay were performed on the basis of all data over the years and at all stations. The common value of Fp for the Peter the Great Bay was calculated after exclusion from shared dataset the values exceeding the percentile $\mathrm{P}_{85}$. The calculation of the mean, median and percentiles $\left(\mathrm{P}_{25}, \mathrm{P}_{75}, \mathrm{P}_{85}\right)$ was performed with Excel. Based on the mean values of $\mathrm{F}_{\mathrm{p}}$, degree of environmental pollution was assessed as light if $\mathrm{F}_{\mathrm{p}}=0.4-0.5$, or as low if $\mathrm{F}_{\mathrm{p}}=0.51-0.8$, or as moderate if $\mathrm{F}_{\mathrm{p}}=0.81-3.5$, or as high if $\mathrm{F}_{\mathrm{p}}=3.51-7.5$, or as heavy pollution if $\mathrm{F}_{\mathrm{p}}>7.5$ (Kozhenkova \& Chernova, 2018).

\section{Results}

In total $\mathrm{I}_{\mathrm{GA}}$ varied in a range of $0.3-7.5$, and $50 \%$ of values (percentile 0.25 0.75 ) changed within the limits of $0.8-1.5$. Based on heavy metal concentrations in $S$. miyabei, $\mathrm{I}_{\mathrm{GA}}$ was lesser than 1 for $56 \%$ of stations in the Peter the Great Bay, and the values of the geochemical anomaly coefficient exceeded 2 at $20 \%$ of stations. These are stations in the Amurskii Bay: Sanatornaya $\left(1995, \mathrm{I}_{\mathrm{GA}}=5.1\right)$ at the expense of contribution of $\mathrm{Mn}, \mathrm{Fe}, \mathrm{Pb}, \mathrm{Zn}$ and $\mathrm{Cu}$ (in descending order of $\mathrm{C}_{\mathrm{i}} / \mathrm{C}_{\text {med }}$, here and further), Tokarevsky Cape $\left(1995, \mathrm{I}_{\mathrm{GA}}=4.0 ; 2002, \mathrm{I}_{\mathrm{GA}}=2.7 ; \mathrm{Mn}\right.$, $\mathrm{Pb}, \mathrm{Fe}, \mathrm{Zn}$ and $\mathrm{Cu})$, Markovsky Cape $\left(2011, \mathrm{I}_{\mathrm{GA}}=3.5\right)$ at the expense of contribution of $\mathrm{Pb}$ and $\mathrm{Cu}$, Pionerskaya Bight $\left(1995, \mathrm{I}_{\mathrm{GA}}=3.3\right.$; $\mathrm{Mn}$ and $\mathrm{Cu}$ ) and other stations situated along the coast of the Muravyov-Amursky Peninsula where the Vladivostok city is situated. In the Ussuriiskii Bay, the largest $\mathrm{I}_{\mathrm{GA}}$ was found for the Desantnaya Bight (7.5 in 2016 and 5.6 in 2017) at the expense of $\mathrm{Cu}, \mathrm{Pb}$ and 
Mn contribution the source of which is the Vladivostok landfill. In Strelok, Vostok and Nakhodka Bays, the stations with $\mathrm{I}_{\mathrm{GA}}>2$ were also revealed. At the same time, the values of $\mathrm{I}_{\mathrm{GA}}$ at stations in Kievka Bight and south-western Peter the Great Bay were not increased.

Heavy metal pollution factor $\left(\mathrm{F}_{\mathrm{p}}\right)$ at different stations in PGB coast has varied in a range of $0.2-4.7$, a percentile $P_{85}$ was equal to 1.0 , thus the mean value of $F_{p}$ $=0.55$. This characterizes the degree of pollution as low.

The water pollution in different parts of the Bay varies from light (south-western part) to moderate one (Amurskii Bay and Ussuriiskii Bay) (Table 1).

In the Amurskii, Ussuriiskii and Vostok Bays the points with moderate degree of heavy-metals pollution $\left(\mathrm{F}_{\mathrm{p}}>0.80\right)$ were identified (Table 2, Figure 2). The

Table 1. Heavy metal pollution factor (Fp) for different parts of the Peter the Great Bay.

\begin{tabular}{ccccc}
\hline Part of the PGB & Median & Mean \pm SD & Range & Water pollution \\
\hline South-West & 0.45 & $0.49 \pm 0.18$ & $0.49-0.79$ & light pollution \\
Amurskii Bay & 0.65 & $0.85 \pm 0.51$ & $0.34-2.67$ & moderate pollution \\
Ussuriiskii Bay & 0.62 & $1.03 \pm 1.06$ & $0.35-4.65$ & moderate pollution \\
Vostok Bay & 0.43 & $0.78 \pm 0.72$ & $0.2-3.13$ & low pollution \\
Nakhodka Bay & 0.52 & $0.52 \pm 0.19$ & $0.26-1.17$ & low pollution \\
Kievka Bight & 0.40 & $0.36 \pm 0.14$ & $0.15-0.51$ & pure \\
\hline
\end{tabular}

Table 2. Heavy metal pollution factor $\left(\mathrm{F}_{\mathrm{p}}\right)$ for polluted locations in Ussuriiskii and Vostok Bays.

\begin{tabular}{|c|c|c|c|c|}
\hline Year & Location & $\mathrm{Fp}$ & Water pollution & Pollutants \\
\hline \multicolumn{5}{|c|}{ Ussuriiskii Bay } \\
\hline 2004 & \multirow[b]{2}{*}{ Gornostay Bight } & 1.30 & moderate pollution & \multirow[t]{2}{*}{$\mathrm{Cu}, \mathrm{Zn}, \mathrm{Pb}$} \\
\hline 2017 & & 0.59 & low pollution & \\
\hline 2016 & \multirow{2}{*}{ Desantnaya Bight } & 4.65 & high pollution & \multirow[t]{2}{*}{$\mathrm{Cu}, \mathrm{Zn}, \mathrm{Pb}, \mathrm{Fe}, \mathrm{Mn}$} \\
\hline 2017 & & 3.17 & moderate pollution & \\
\hline 2002 & $2 \mathrm{~km}$ to the north from the Desantnaya Bight & 1.95 & moderate pollution & $\mathrm{Cu}, \mathrm{Pb}, \mathrm{Ni}$ \\
\hline 2010 & \multirow[b]{2}{*}{ Muravinaya Bight } & 0.85 & moderate pollution & \multirow[t]{2}{*}{$\mathrm{Fe}, \mathrm{Mn}, \mathrm{Ni}, \mathrm{Cd}$} \\
\hline 2017 & & 1.22 & moderate pollution & \\
\hline 2010 & Telakovskogo Bight & 0.89 & moderate pollution & $\mathrm{Fe}, \mathrm{Mn}, \mathrm{Ni}$ \\
\hline \multicolumn{5}{|c|}{ Vostok Bay } \\
\hline 2002 & & 1.18 & moderate pollution & \multirow[t]{3}{*}{$\mathrm{Cu}, \mathrm{Zn}, \mathrm{Pb}, \mathrm{Mn}$} \\
\hline 2003 & Gaydamak Bight & 1.18 & moderate pollution & \\
\hline 2004 & & 0.78 & low pollution & \\
\hline 2002 & Srednaya Bight & 0.94 & moderate pollution & $\mathrm{Zn}, \mathrm{Pb}$ \\
\hline 2002 & Tihaya Bight & 2.25 & moderate pollution & $\mathrm{Cu}, \mathrm{Zn}, \mathrm{Pb}$ \\
\hline 2002 & Noth-western part of the Bay & 0.85 & moderate pollution & $\mathrm{Fe}, \mathrm{Mn}$ \\
\hline 2002 & Northern part of the Bay & 1.12 & moderate pollution & $\mathrm{Fe}, \mathrm{Mn}$ \\
\hline
\end{tabular}


high pollution level was determined on the western coast of the Ussuriiskii Bay near the Vladivostok city landfill $\left(\mathrm{F}_{\mathrm{p}}>3.50\right)$. The total number of sampling stations with excess of the threshold levels of heavy metals in $S$. miyabei reached 24, thus, based on the degree of pollution, $30 \%$ of inspection sites are characterized by moderate or higher pollution.

A long-term monitoring of the heavy metal pollution degree based on $\mathrm{F}_{\mathrm{p}}$ in 1995-1998, 2000-2005, 2008-2012 and 2015-2017 was carried out for the following three areas of the Peter the Great Bay: south-western part, Amurskii Bay and Nakhodka Bay (Figure 3). A value of $\mathrm{F}_{\mathrm{p}}$ for the south-western part of the Bay varied from $0.55 \pm 0.19$ in 2000-2005 to $0.34 \pm 0.09$ in 2015-2017 (low pollution $\rightarrow$ pure), in Amurskii Bay from $0.95 \pm 0.49$ in 1995-1998 to $0.65 \pm 0.37$ in 2015-2017 (moderate pollution $\rightarrow$ low pollution), and in Nakhodka Bay from $0.54 \pm 0.36$ in 1995-1998 to $0.50 \pm 0.12$ in 2008-2012 (low pollution $\rightarrow$ light pollution).

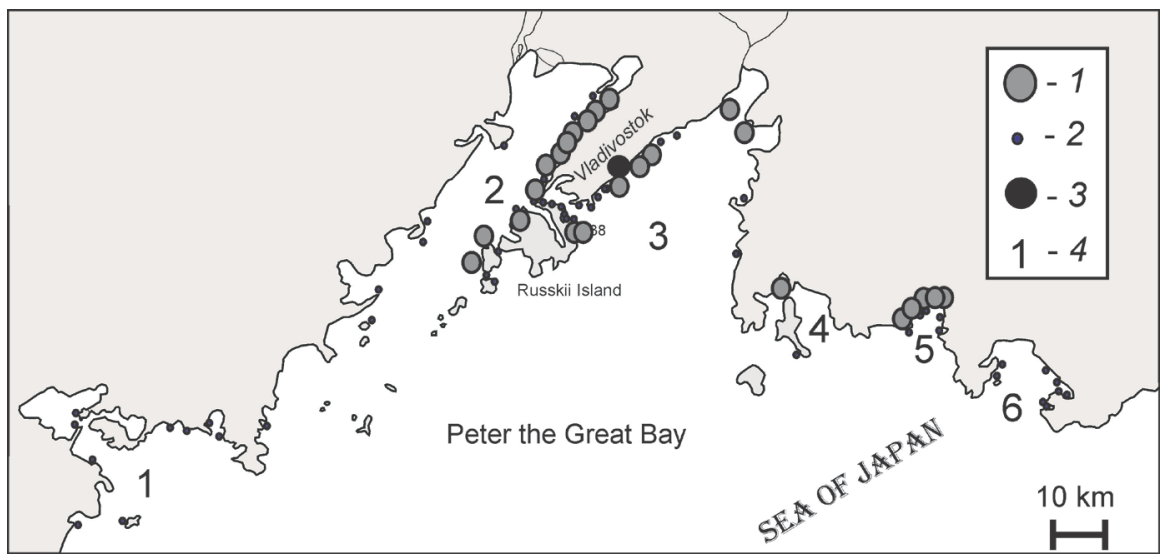

Figure 2. Heavy metal pollution in the Peter the Great Bay, Sea of Japan: 1-locations with $\mathrm{Fp}>0.8 ; 2$-locations with $\mathrm{F}_{\mathrm{p}} \leq 0.8,3$-Vladivostok city landfill, 4-parts of PGB (1-south-western part, 2-Amurskii Bay, 3-Ussuriiskii Bay, 4-Strelok Bay, 5-Vostok Bay, 6-Nakhodka Bay).

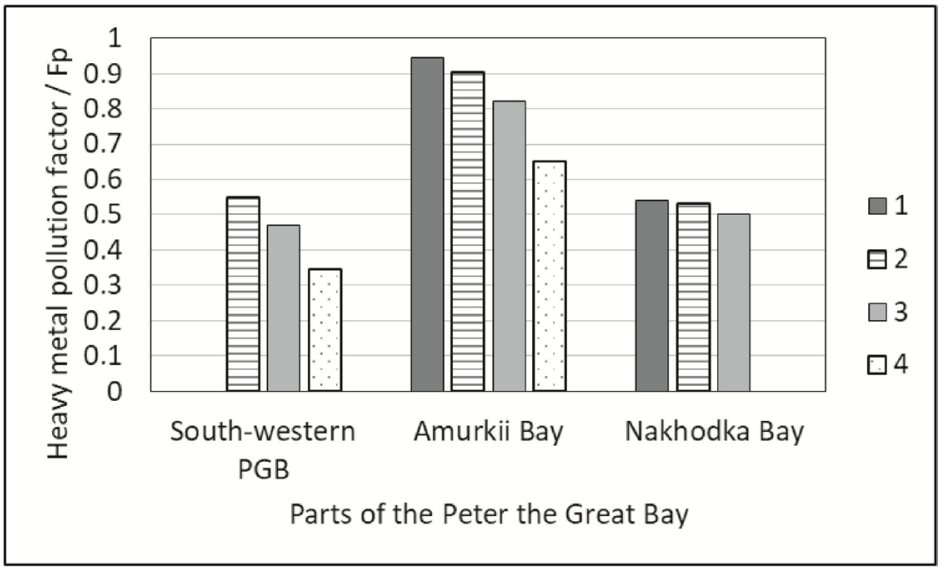

Figure 3. Change in the heavy metal pollution degree in different parts of the Peter the Great Bay at the end of XX-at the beginning of XXI centuries: 1) 1995-1998, 2) 2000-2005, 3) 2008-2012, 4) 2015-2017. 


\section{Discussion}

The determination of the space structure of pollution differentiating the territory with respect to level of ecological hazard is the crucial task of the geochemical surveys of environment.

The main routes of metals to the marine environment are river runoff and atmospheric deposition (Shulkin, 2012). The anthropogenic sources of pollutants such as sewage waters of manufacturing facilities and residential areas, land drainage from the urbanized terrains and municipal solid waste landfills, corrosion of the facilities of port infrastructure and ship bottoms, sunken floating crafts and some other objects change the natural geochemical flows of elements.

The different parts of the Peter the Great Bay are characterized by different sources of pollutants to the sea. In 1980s-1990s, the degree of anthropogenic impact and volume of entry of the organic and inorganic pollutants to different parts of the Bay fell in the following sequence: Amurskii Bay > Ussuriiskii Bay > Nakhodka Bay > Strelok Bay > Vostok Bay, Posyet Bay > FESMR (Ogorodnikova, 2001; Shulkin, 2004). Decline in the volumes of industrial and agricultural outputs in the late 1990s resulted in decrease of pollutants entry to the coastal seawaters (Lukyanova, Cherkashin, \& Simokon, 2012).

Determination of the pollution degree of the environment by different chemicals is based on the principle of comparison of their actual concentrations in water, bottom sediments, soil or air with accepted ecological standards such as maximum permissible concentrations (Guidelines..., 1988; Shiriev, 2005). The concentrations of metals in the abundant species of marine organisms-bivalves, brown and green algae-are also used as indicators of the marine environment state (Amado-Filho, Salgado, Rebelo, Rezende, Karez, \& Pfeiffer, 2008; Pan, Wernberg, de Bettignies, Holmer, Li, Wu et al., 2018; Sun, Liu, Jiang, \& Yang, 2019) throughout the comparison with the background values. Maximum permissible concentrations for organisms were not determined yet, but there are several approaches to their determination (Cantillo, 1998; Reinmann, Filzmoser, \& Garrett, 2005; Lukashev, 2007; Zalewska \& Danowska, 2017). In many countries, the health-based exposure limits were approved for determining the safety in use of bioresources but they are not in line with goals of maintaining the stability of ecosystems.

The degree of environmental hazard of territory and water area can be determined using the different kinds of combined and/or integrated pollution indices. The international Metal Pollution Index (MPI) proposed by J. Usero with coauthors (1996), in its current form, only allows to compare the global trace metal pollution between the different monitored sites of a specific survey, for a given species (Richir \& Gobert, 2014). Hereafter, two new adapted indices-TESVI (Trace Element Spatial Variation Index) and TEPI (Trace Element Pollution Index) - which were based on account of the statistically average values-mean standard deviation, maximum and minimum values of metal concentrations in a dataset were proposed (Richir \& Gobert, 2014). 
Based on the study of C. Reinmann with coauthors (2005), we have calculated the background and threshold heave metal concentrations in algae of the coastal part of the Sea of Japan (Chernova, 2012; Chernova \& Kozhenkova, 2016), as well as for Okhotsk Sea, White Sea and South China Sea (Chernova \& Khristoforova, 2012).

Brown algae are the integral indicators of heavy metal pollution in the coastal waters (Rainbow \& Phillips, 1993; Vasquez \& Guerra, 1996; Shulkin, Chernova, Khristoforova, \& Kozhenkova, 2015; Chernova \& Kozhenkova, 2016; Pan, Wernberg, de Bettignies, Holmer, Li, Wu et al., 2018). Biogeochemical coefficients reflect the features of the microelement composition of the brown alga $S$. miyabei in the different localities or within a "separate" water area (Table 1, Table 2). A value of $\mathrm{I}_{\mathrm{GA}}$ (algae geochemical anomaly index) assesses the features of the content of the metal complex in algae with respect to the background conditions. As the background concentration, the median of the dataset with the excluded statistical outliers was used. Therefore, $\mathrm{I}_{\mathrm{GA}}=1$ corresponds to the background level of metals in the alga. If a value of $\mathrm{I}_{\mathrm{GA}}<2$, the algae grow in the environment with natural level of metal content (Chernova \& Kozhenkova, 2020). However, at $\mathrm{I}_{\mathrm{GA}}>2$, the anthropogenic effect on the entry of metals to the marine environment becomes deciding. In the Peter the Great Bay, the stations with $\mathrm{I}_{\mathrm{GA}}>2$ are located on the eastern coast of the Amurskii Bay and western coast of the Ussuriiskii Bay and related to heavy metal pollution from the industrial and municipal sewage waters of Vladivostok, washout of pollutants on the town landfill territory and effect of the port. In the Strelok, Vostok and Nakhodka Bays, the stations with $\mathrm{I}_{\mathrm{GA}}>2$ are located near ports and outlets of polluted wastewaters from populated areas.

Different metals are characterized by different toxicities for the marine organisms (Chu \& Chow, 2002; Golovanova, 2008; Mebane, Hennessy, \& Dillon, 2008). Heavy metal pollution factor $\left(F_{p}\right)$ characterizes the enrichment of algae with heavy metals with respect to the threshold levels and with consideration for the hazard class for marine organisms. All the chemical substances in the fishery water bodies were separated into 4 hazard classes (Fe, $\mathrm{Mn}-4$; $\mathrm{Cu}, \mathrm{Zn}, \mathrm{Ni}-3$; $\mathrm{Cd}, \mathrm{Pb}-2$; Order..., 2016). The stations with the largest values of Fp are rated as most dangerous from the toxicological standpoint for the marine biota. Therefore, the measures related to reducing the volumes of metal entry to the coastal seawaters in such areas should be carried out in the first place.

According to $\mathrm{F}_{\mathrm{p}}$ value for $S$. miyabei the pollution degree of PGB water areas is rated as low. Different parts of the second-order bays, such as Amurskii, Ussuriiskii and Vostok Bays, have a moderate degree of pollution (Figure 2, Table 2). The high pollution level was determined on the western coast of the Ussuriiskii Bay near the Vladivostok city landfill (Table 2).

Our conclusions of the degree of the Peter the Great Bay pollution with heavy metals confirm and supplement the data on monitoring of this Bay pollution with the use of the bottom sediments (BS). Generally, the content of metals in 
the BS of the Bay characterizes the ecosystem state as advantageous (Dudarev, Botsul, Charkin, Biryulina, \& Gavrilova, 2002). Bottom sediments within the Port of Vladivostok, i.e. in the Golden Horn Bay and Diomid Bight, are heavily polluted by metals. The concentrations of lead, cadmium, mercury, zinc and copper in the BSs of these water areas exceed 10 and more times the background level (Shulkin, 2004). The brown algae S. miyabei were not found within the Port of Vladivostok, so we have not data on heavy metal concentration in the macroalgae from this area. In the south-eastern part of the Amurskii Bay, a zone with concentrations of $\mathrm{Pb}, \mathrm{Cd}, \mathrm{Cu}$ and $\mathrm{Zn}$ in $\mathrm{BS}$ exceeding the background values 1.5 - 3 times has formed which is probably caused by damping of contaminated sediments from the Port of Vladivostok. In the south-western coast of the Ussuriiskii Bay the BS contain $\mathrm{Pb}, \mathrm{Cu}$ and $\mathrm{Zn}$ with concentrations higher 2 - 3 times than the background levels. The maximal metal pollution of sediments was recorded near the municipal landfill on the western coast of the Ussuriiskii Bay: more than 13-fold excess of the background for $\mathrm{Pb}, \mathrm{Cd}, \mathrm{Hg}$ and $\mathrm{Cu}$ (Lukyanova, Cherkashin, \& Simokon, 2012; Shulkin \& Semykina, 2012).

Reduction in the volumes of industrial and agricultural production in the south of the Russian Far East in the late 1990s has resulted in decreasing the volumes of pollutants (Brief..., 2016). The tendency to reducing the degree of heavy metal pollution in the Peter the Great Bay for the period from the end of the XX century to early XXI century was revealed on the basis of $\mathrm{F}_{\mathrm{p}}$ values for brown alga $S$. miyabei (Figure 3, Table 2). A lowering in content of different pollutants in the sea water and bottom sediments of PGB was also recorded. The ecotoxicological situation in the most polluted water areas improved (Cherkashin, Simokon, \& Pryazhevskaya, 2019). It has been established that the state of the benthos and fishes community was stable. The ichthyofauna of the Peter the Great Bay remains rich in species composition and the density of fish concentration is high here. Biomass of fishes is little different in the Amurskii $\left(11.6 \mathrm{t} / \mathrm{km}^{2}\right)$ and Ussuriiskii $\left(12.2 \mathrm{t} / \mathrm{km}^{2}\right)$ Bays as well as in the open Peter the Great Bay. In the Amurskii Bay, the effect of pollution from the sewer outfalls is only recorded in the north-eastern part of the Bay where the harvestings of many species of fishes, especially flounders, became smaller (Lukyanova, Cherkashin, \& Simokon, 2012).

Over the last years, a growth of oil transportation and volume of agricultural production are observed in the southern Far East of Russia. It can increase the input of pollutants including heavy metals to the catchment basin of the Peter the Great Bay. For this reason, the monitoring of marine environment should be continued.

\section{Acknowledgements}

We are grateful to our colleagues, the analytical engineers G.A. Vlasova and A.M. Plotnikova, for their assistance in the preparation and analysis of samples. 


\section{Funding}

The research results were obtained within the framework of the State Assignment from the Ministry of Education and Science of the Russian Federation (project no. AAAA-A16-116111610032-5).

\section{Conflicts of Interest}

The authors declare no conflicts of interest regarding the publication of this paper.

\section{References}

Al-Masri, M. S., Mamish, S., \& Budier, Y. (2003). Radionuclides and Trace Metals in Eastern Mediterranean Sea Algae. Journal of Environmental Radioactivity, 67, 157-168. https://doi.org/10.1016/S0265-931X(02)00177-7

Amado-Filho, G. M., Salgado, L. T., Rebelo, M. F., Rezende, C. E., Karez, C. S., \& Pfeiffer, W. C. (2008). Heavy Metals in Benthic Organisms from Todosos Santos Bay, Brazil. Brazilian Journal of Biology, 68, 95-100. https://doi.org/10.1590/S1519-69842008000100013

Brief Statistical Compilation (2016). Primorye in Numbers. 2015. Vladivostok: Primorskstat Press.

Brito, G. B., de Souza, T. L., Bressy, F. C., Moura, C. W. N., \& Korn, M. G. A. (2012). Levels and Spatial Distribution of Trace Elements in Macroalgae Species from the Todosos Santos Bay, Bahia, Brazil. Marine Pollution Bulletin, 64, 2238-2244. https://doi.org/10.1016/j.marpolbul.2012.06.022

Bryan, G. W., \& Hummerstone, L. G. (1973). Brown Seaweeds as an Indicator of Heavy Metals in Estuaries in South-West England. J. Mar. Biol. Assoc. U. K., 53, 705-720. https://doi.org/10.1017/S0025315400058902

Burdin, K. S. (1985). Outlines of Biological Monitoring. Moscow: Moscow State University Press.

Cantillo, A. Y. (1998). Comparison of Results of Mussel Watch Programs of the United States and France with Worldwide Mussel Watch Studies. Marine Pollution Bulletin, 36, 712-717. https://doi.org/10.1016/S0025-326X(98)00049-6

Chakraborty, S., Bhattacharya, T., Singh, G., \& Maity, J. P. (2014). Benthic Macroalgae as Biological Indicators of Heavy Metal Pollution in the Marine Environments: A Biomonitoring Approach for Pollution Assessment. Ecotoxicology and Environmental Safety, 100, 61-68. https://doi.org/10.1016/j.ecoenv.2013.12.003

Cherkashin, S. A., Simokon, M. V., \& Pryazhevskaya, T. S. (2019). Analysis of the Ecotoxicological Conditions of Amur Bay, the Sea of Japan, by Chemical and Toxicological Characteristics. Water Resources, 46, 432-442. https://doi.org/10.1134/S0097807819030059

Chernova, E. N. (2012). Determination of the Background Ranges of Trace Metals in the Brown Alga Sargassum pallidum from the Northwestern Sea of Japan. Russian Journal of Marine Biology, 38, 267-274. https://doi.org/10.1134/S1063074012030030

Chernova, E. N., \& Khristoforova, N. K. (2012). Algae Sargassum as an Indicator of Trace Metal Pollution of South China Sea Coastal Waters. Environmental Research Journal, 6, 328-338.

Chernova, E. N., \& Kozhenkova, S. I. (2016). Determination of Threshold Concentrations 
of Metals in Indicator Algae of Coastal Waters in the Northwest Sea of Japan. Oceanology, 56, 363-371. https://doi.org/10.1134/S0001437016030024

Chernova, E. N., \& Kozhenkova, S. I. (2020). Spatial Assessment of Pollution of Peter the Great Bay (Sea of Japan) by Metals Using Brown Algae Sargassum miyabei. Oceanology. (In Press) https://doi.org/10.1134/S0001437020010051

Chernova, E. N., \& Sergeeva, O. S. (2008). Metal Concentrations in Sargassum Algae from Coastal Waters of Nha Trang Bay (South China Sea). Russian Journal of Marine Biology, 34, 57-63. https://doi.org/10.1134/S1063074008010082

Chernova, E. N., Khristoforova, N. K., \& Vyshkvartsev, D. I. (2002). Heavy Metals in Seagrasses and Algae of Poset Bay, Sea of Japan. Russian Journal of Marine Biology, 28, 387-392. https://doi.org/10.1023/A:1021849114166

Chu, K. W., \& Chow, K. L. (2002). Synergistic Toxicity of Multiple Heavy Metals Is Revealed by a Biological Assay Using a Nematode and Its Transgenic Derivative. Aquatic Toxicology, 61, 53-64. https://doi.org/10.1016/S0166-445X(02)00017-6

Dudarev, O. V., Botsul, A. I., Charkin, A. N., Biryulina, M. G., \& Gavrilova, G. S. (2002). Recent Geoecological Situation in Peter the Great Bay (Sea of Japan). Izvestia TINRO (Transactions of the Pacific Research Institute of Fisheries and Oceanography), 131, $132-140$

Fuge, R., \& James, K. H. (1974). Trace Metal Concentration in Fucus from the Bristol Channel. Marine Pollution Bulletin, 5, 9-12. https://doi.org/10.1016/0025-326X(74)90026-5

Golovanova, I. L. (2008). Effect of Heavy Metals on Physiological and Biochemical Status of Fishes and Aquatic Invertebrates. Inland Water Biology, 1, 99-108. https://doi.org/10.1007/s12212-008-1014-1

Guidelines for a Formalized Comprehensive Assessment of the Quality of Surface and Sea Waters by Hydrochemical Indicators (1988). Moscow, USSR State Committee for Hydrometeorology. https://doi.org/10.1111/dmcn.12066 http://www.oceanography.ru/index.php/2013-10-25-13-45-55/2013-05-24-14-27-12

Ho, Y. B. (1988). Metal Levels in Three Intertidal Macroalgae in Hong Kong Waters. $A q$ uatic Botany, 29, 367-372. https://doi.org/10.1016/0304-3770(88)90080-0

Hou, X., \& Yan, X. (1998). Study on the Concentration and Seasonal Variation of Inorganic Elements in 35 Species of Marine Algae. Science of the Total Environment, 222, 141-156. https://doi.org/10.1016/S0048-9697(98)00299-X

Israel, Y. A. (1989). Anthropogenic Ecology of the Ocean. Leningrad: Hydrometeoizdat.

Khristoforova, N. K. (1989). Bioindication and Monitoring of Heavy Metal Pollution of Sea Water. Leningrad: Science.

Khristoforova, N. K., \& Kobzar, A. D. (2017). Assessment of Ecological State of the Posyet Bay (The Sea of Japan) by Heavy Metals Content in Brown Algae. Samara Scientific Bulletin, 6, 91-95.

Khristoforova, N. K., Bogdanova, N. N., \& Tolstova, L. M. (1983). Metals in Pacific Sargasso Algae in Connection with the Problem of Monitoring Water Pollution. Oceanology, 23, 270-275.

Khristoforova, N. K., Emelyanov, A. A., \& Efimov, A. V. (2018). Bioindication of Heavy-Metal Pollution in the Coastal Marine Waters of Russky Island (Peter the Great Bay, Sea of Japan). Russian Journal of Marine Biology, 44, 572-579. https://doi.org/10.1134/S1063074018070040

Khristoforova, N. K., Gamayunova, O. A., \& Afanasyev, A. P. (2015). State of the Kozmin and Wrangel Bays (Peter the Great Bay, Japan Sea): Dynamics of Pollution with Heavy 
Metals. Izvestia TINRO (Transactions of the Pacific Research Institute of Fisheries and Oceanography), 180, 179-186.

Kobzar, A. D., \& Khristoforova, N. K. (2015). Monitoring Heavy-Metal Pollution of the Coastal Waters of Amursky Bay (Sea of Japan) Using the Brown Alga Sargassum miyabei Yendo, 1907. Russian Journal of Marine Biology, 41, 384-388. https://doi.org/10.1134/S1063074015050065

Kozhenkova, S. I., \& Chernova, E. N. (2018). A Method for Determining Pollution of Marine Coastal Waters by Heavy Metals Using Macroalgae. RF Patent No. 2655441.

Kozhenkova, S. I., Khristoforova, N. K., \& Chernova, E. N. (2000). Long-Term Monitoring of Sea Water Pollution by Heavy Metals in Northern Primorye with the Use of Brown Algae. Russian Journal of Ecology, 31, 211-215.

https://doi.org/10.1007/BF02762825

Lukashev, D. V. (2007). A Method for Calculating Background Concentrations of Heavy Metals in Soft Tissues of Bivalve Mollusks to Assess Pollution of the Dnieper River. Biology of Inland Waters, 4, 97-106.

Lukyanova, O. N., Cherkashin, S. A., \& Simokon, M. V. (2012). The Review of Modern Ecological State of Peter the Great Bay (2000-2010). Bulletin of the Far Eastern Branch of the Russian Academy of Sciences, 2, 55-63.

Mebane, C. A., Hennessy, D. P., \& Dillon, F. S. (2008). Developing Acute-to-Chronic Toxicity Ratios for Lead, Cadmium, and Zinc Using Rainbow Trout, a Mayfly, and a Midge. Water, Air and Soil Pollution, 188, 41-66.

https://doi.org/10.1007/s11270-007-9524-8

Ogorodnikova, A. A. (2001). Ecological and Economic Assessment of the Impact of Coastal Pollution Sources on the Environment and Biological Resources of the Peter the Great Bay. Vladivostok: TINRO Center Press.

Order of the Ministry of Agriculture of the Russian Federation (2016). On Approval of Water Quality Standards for Water Bodies of Fishery Purposes, Including Standards of Maximum Permissible Concentrations of Harmful Substances in Water Bodies of Fishery Purposes. https://docviewer.yandex.ru/view/

Pan, Y., Wernberg, T., de Bettignies, T., Holmer, M., Li, K., Wu, J. et al. (2018). Screening of Seaweeds in the East China Sea as Potential Bio-Monitors of Heavy Metals. Environmental Science and Pollution Research, 25, 16640-16651. https://doi.org/10.1007/s11356-018-1612-3

Rainbow, P. S., \& Phillips, D. J. H. (1993). Cosmopolitan Biomonitors of Trace Metals. Marine Pollution Bulletin, 26, 593-601. https://doi.org/10.1016/0025-326X(93)90497-8

Reinmann, C., Filzmoser, P., \& Garrett, R. G. (2005). Background and Threshold Critical Comparison of Methods of Determination. Science of the Total Environment, 346, 1-16. https://doi.org/10.1016/j.scitotenv.2004.11.023

Richir, J., \& Gobert, S. (2014). A Reassessment of the Use of Posidonia oceanica and Mytilus galloprovincialis to Biomonitor the Coastal Pollution of Trace Elements: New Tools and Tips. Marine Pollution Bulletin, 89, 390-406.

https://doi.org/10.1016/j.marpolbul.2014.08.030

Shiriev, R. R. (2005). On the Issue of Optimizing the Methodology for Determining the Integral Indicator of Water Body Pollution. Modern High Technology, 6, 79-82.

Shulkin, V. M. (2004). Metals in Shallow Marine Ecosystems. Vladivostok: Dalnauka.

Shulkin, V. M. (2012). Comparative Assessment of the Aerial and Fluvial Inputs of Matter into Marine Ecosystems. Geography and Natural Resources, 33, 172-176. 
https://doi.org/10.1134/S1875372812020114

Shulkin, V. M., \& Semykina, G. I. (2012). Input of Pollutants in Peter the Great Bay and Assessment of Their Role in Forming of Ecological Problems. In N. K. Khristoforova (Ed.), Current Ecological State of Peter the Great Bay, Sea of Japan (pp. 252-287). Vladivostok: Far Eastern Federal University Press.

Shulkin, V. M., Chernova, E. N., Khristoforova, N. K., \& Kozhenkova, S. I. (2015). Effect of Mining Activities on the Chemistry of Aquatic Ecosystem Components. Water Resources, 42, 843-853. https://doi.org/10.1134/S009780781507012X

Sun, X., Liu, Z., Jiang, Q., \& Yang, Y. (2019). Concentrations of Various Elements in Seaweed and Seawater from Shen'ao Bay, Nan'ao Island, Guangdong Coast, China: Environmental Monitoring and the Bioremediation Potential of the Seaweed. Science of the Total Environment, 659, 632-639. https://doi.org/10.1016/j.scitotenv.2018.12.364

Usero, J., González-Regalado, E., \& Gracia, I. (1996). Trace Metals in the Bivalve Mollusk Chamelea gallina from the Atlantic Coast of Southern Spain. Marine Pollution Bulletin, 32, 305-310. https://doi.org/10.1016/0025-326X(95)00209-6

Vasquez, J. A., \& Guerra, N. (1996). The Use of Seaweeds as Bioindicators of Natural and Anthropogenic Contaminants in Northern Chile. Hydrobiologia, 326/327, 327-333. https://doi.org/10.1007/BF00047826

Zalewska, T., \& Danowska, B. (2017). Marine Environment Status Assessment Based on Macrophytobenthic Plants as Bio-Indicators of Heavy Metals Pollution. Marine Pollution Bulletin, 118, 281-288. https://doi.org/10.1016/j.marpolbul.2017.02.075 